\title{
Response of Essential Oil and Terpene Contents of Two Mint Genotypes to Different Drying Temperatures before Distillation
}

\author{
Fathy Saad El-Nakhlawy ${ }^{1}$, Mohamed Abdulraheem Shaheen ${ }^{1} \&$ Abdulmohsin Rajeh Al-Shareef ${ }^{2}$ \\ ${ }^{1}$ Arid Land Agriculture Dept., Faculty of Meteorology, Environment and Arid Land Agriculture, King Abdulaziz \\ University, Jeddah, Saudi Arabia \\ ${ }^{2}$ Geography and Information System Dept., Faculty of Arts and Humanities, King Abdulaziz University, Jeddah, \\ Saudi Arabia \\ Correspondence: Fathy Saad El-Nakhlawy, Arid Land Agriculture Dept., Faculty of Meteorology, Environment \\ and Arid Land Agriculture, King Abdulaziz University, Jeddah, Saudi Arabia. Tel: 966-504-453-978. E-mail: \\ falnakhlawi@kau.edu.sa
}

Received: September 22, 2013 Accepted: October 8, 2013 Online Published: November 15, 2013

doi:10.5539/jas.v5n12p126 URL: http://dx.doi.org/10.5539/jas.v5n12p126

\begin{abstract}
Two mint genotypes (Hassawi and Baladi) were evaluated in their essential oil and terpene components under 6 drying treatments after harvesting and before oil distillation in Faculty of Met., Env. and Arid Land Agriculture, King Abdulaziz Univ., Saudi Arabia. Hassawi cv. significantly higher in oil content than Baladi cv. The main terpene components were Menthone (27.71\% in Hassawi cv. and 24.04\% in Baladi cv.) and Menthol (71.89\% in Hassawi cv. and $24.02 \%$ in Baladi cv.). Menthone and Menthal concentrations significantly decreased as plant leaves were dried $>60^{\circ} \mathrm{C} / 14$ days. As drying temperature increased by $1{ }^{\circ} \mathrm{C}$ essential oil, Menthone and Menthol decreased by $0.005,0.013$ and $0.071 \%$, respectively. Correlation coefficients were 0.96 and 0.94 between oil (\%) and Menthone and Menthol, respectively.
\end{abstract}

Keywords: drying, essential oil, menthone, menthol, mint, terpene

\section{Introduction}

Mint is an important economical plant; the essential oil extracted from the aerial plant parts over the soil is used in many uses such as chewing gum, tooth paste, as a flavor in many sweet kinds and some of medicinal drugs (Rohloff, 1999). Biosynthesis and storage of essential oil in mint species is restricted to the oil glands on the aerial surface of the plant (Croteau et al., 2005; Mocaskil et al., 1992). Aromatic plants are affected by the genetic makeup, environmental factors during growing storage and the interaction between genetic makeup and environment (Clark \& Menary, 1980). The total essential oil biosynthesis and its quality depend on the genetic makeup of the plant (Franz et al., 1984). The concentration of essential oil and composition of the mint genotypes are affected by the interaction between genotype and environment, storage conditions, and season of mint growing (Kofides et al., 2004; Kumar et al., 2000; Cholchot et al., 1997).

Post harvest conditions and processing of the plant during storage such as drying may cause reduction of oil quality (Fennell et al., 2004; Arabhosseini et al., 2007). Also, oil (\%) decreased during the storage time under drying conditions of mint (Singh et al., 1990). Monoterpenes percentage in peppermint increased, while the percentage of monoterpene Kitones decreased as glycolytes oxidation increased (Maffei \& Codignola, 1990).

This study was conducted to evaluate the main mint genotypes cultivated in Saudi Arabia concerning essential oil and its components from terpens under the effects of different temperatures of plant drying before extraction the oil, also, study the relationship between drying temperature and oil content and its components from terpene using the regression analysis besides the trend and power of the different mint oil characteristics in the form of correlation coefficients.

\section{Materials and Methods}

\subsection{Field Growing}

The two main mint genotypes (Mentha arvensis L. and Mentha piperita) were grown in Saudi Arabia under the commercial names of Hassawi and Baladi were planted at the Agricultural Research Station, Hada Al-Sham, 
King Abdulaziz University under the same conventional culture practices. The guarded plants were harvested and their leaves were separated before appearance the first flower.

The separated leaves used to study the effects of 5 drying temperatures for 14 days before oil distillation besides the fresh plant distillation without drying.

\subsection{Extraction the Essential Oil}

The essential oil content in mint leaves were extracted using the Steam Distillator according to A.O.A.C. (2000). The fresh and dried mint materials were extracted in the instruments for 100 minutes.

\subsection{Essential Oil Analysis}

Essential oil from the 48 samples of the studied treatments were analyzed using GC (a Varian 3700 Gas Chromotography) and GC-MS (mass spectrometer) to identification the terpene compounds of the essential oil samples (Massada, 1976; Adam, 2001).

\subsection{Experimental Design}

Split plot designs with 4 replicates were used where the 2 mint genotypes were the main plot treatments and the 6 drying treatments were the sub plot treatments.

\subsection{Statistical Analysis}

The obtained data were statistically analyzed using analysis of variance and mean separation by BLSD and the regression and correlation analysis was done according to El-Nakhlawy (2010) using SAS (2006).

\section{Results and Discussion}

\subsection{Effect of Mint Genotype}

\subsubsection{Essential Oil}

Comparing the 2 mint genotypes in essential oil, data in Table 1 showed that Hassawi cv. significantly higher in oil than Baladi mint. Means of the $2 \mathrm{cvs}$. in essential oil were $1.40 \%$ and $1.02 \%$, respectively. The significant difference in oil content may be due to the difference in the genetic-makeup and the interaction between the genotype and the environment (Clark \& Menary, 1980; Franz et al., 1984; Kofides et al., 2004).

\subsubsection{Terpene Compounds}

Significantly differences were found between the essential oil contents from the terpene compounds (\%) between the 2 mint genotypes (Table 1).

Table 1. Means of essential oil (\%) and its terpene compounds (\%) of the 2 mint genotypes

\begin{tabular}{ccc}
\hline \multirow{2}{*}{ Composition } & \multicolumn{2}{c}{ Means (\%) } \\
\cline { 2 - 3 } & Hassawi & Baladi \\
\hline Essential oil content & $1.40 \mathrm{a}^{*}$ & $1.02 \mathrm{~b}$ \\
Menthone & $4.04 \mathrm{~b}$ & $27.71 \mathrm{a}$ \\
Iso-Menthone & $6.26 \mathrm{~b}$ & $8.14 \mathrm{a}$ \\
Menthol & $71.89 \mathrm{a}$ & $24.02 \mathrm{~b}$ \\
Cineol & $3.07 \mathrm{~b}$ & $4.20 \mathrm{a}$ \\
Limonene & $2.08 \mathrm{a}$ & $2.19 \mathrm{a}$ \\
Carvone & $0.97 \mathrm{a}$ & $0.97 \mathrm{a}$ \\
Myrecene & $1.03 \mathrm{a}$ & $0.49 \mathrm{~b}$ \\
$\alpha-$ Pinene & $0.62 \mathrm{a}$ & $0.75 \mathrm{a}$ \\
$\beta$-Pinene & $0.86 \mathrm{~b}$ & $1.11 \mathrm{a}$ \\
\hline
\end{tabular}

*, Means of each component followed by the same letter are not significantly different according to BLSD at $\mathrm{p} \leq$ 0.05 , respectively. 
Hassawi genotype significantly dominated on the Baladi mint genotype in Menthol and Myrecene terpens, where menthol concentrations were $71.89 \%$ and $24.02 \%$ in Hassawi and Baladi mint oil, respectively and Myrecene (\%) were 1.03 and $0.49 \%$, respectively. Baladi mint oil terpene content were higher than Hassawi genotypes in Menthone, IsoMenthone, Cineol and $\beta$-Pinene where these terpene compounds were $27.72 \%, 8.14 \%, 4.20 \%$, and $1.11 \%$, respectively in Baladi mint, while in Hassawi genotype were $4.04 \%, 6.26 \%, 3.07 \%$ and $0.86 \%$, respectively as shown in Table 1.

These results may be due to the effects of the genetic-makeup, environmental factors and the interaction between the genetic makeup and environment during growing, essential oil biosynthesis and storage in plant tissues and the response of each studied genotypes to these factors (Croteau et al., 2005; McCaskill et al., 1992; Clark \& Menary, 1980; Franz et al., 1984; Kofides et al., 2004; Kumar, 2000).

\subsection{Effect of Drying Temperature}

According to the results of analysis of variance concerning with no significant effects were showed between the genotypes and drying treatments the results will concentrate on the effect of temperature treatments over both genotypes.

Six drying temperatures were used in this study to investigate their effects on essential oil (\%), and essential oil composition from terpene compounds.

\subsubsection{Essential Oil Content}

The obtained results of mint essential oil contents under the 6 drying treatments (Table 2) showed that the essential oil contents (\%) were significantly similar under the drying of $40^{\circ} \mathrm{C}$ and the fresh leaves without drying with means of 1.40 and $1.44 \%$, respectively. Under the drying of $60^{\circ} \mathrm{C}$ or more significantly gradually decreasing in essential oil of the mint leaves were noticed. Essential oil contents (\%) were 1.32, 1.13, 1.01 and $0.92(\%)$ under $60^{\circ} \mathrm{C}, 80^{\circ} \mathrm{C}, 100^{\circ} \mathrm{C}$ and $120^{\circ} \mathrm{C}$ drying treatments, respectively. These results were due to the effect of high temperature after harvesting on evaporation of essential oil from stomata, which reflected into decreasing in mint oil under the temperatures more than $40^{\circ} \mathrm{C}$ (Fennell et al., 2004; Arabhosseini et al., 2007; Singh et al., 1990).

\subsubsection{Terpene Compounds}

The obtained results (Table 2) showed that Menthone contents in the essential oil under the different drying treatments were not significantly different under the fresh extraction, 40 and $60^{\circ} \mathrm{C}$ drying treatments but after $60^{\circ} \mathrm{C}$ Menthone significantly decreased. No significant difference between Iso-Menthone (\%) in fresh leaves or $40^{\circ} \mathrm{C}$, while significantly decreasing in Iso-Menthone as drying temperature increased after $40^{\circ} \mathrm{C}$. Menthol content is the highest essential oil terpene (\%) where it contains around $43-52 \%$ from the oil. Menthol (\%) was significantly equal in the essential oil extracted from the fresh mint leaves and after drying for 14 days under $40^{\circ} \mathrm{C}$. Significantly decreasing in Menthol (\%) as drying temperature increased from $60^{\circ} \mathrm{C}$ to $120^{\circ} \mathrm{C}$. Around $6 \%$, $10 \%, 14 \%$ and $17 \%$ depression in Menthol contents as mint leaves were lifted to dry under $60^{\circ} \mathrm{C}, 80^{\circ} \mathrm{C}, 100^{\circ} \mathrm{C}$ or $120^{\circ} \mathrm{C}$ for 14 days comparing with drying under $40^{\circ} \mathrm{C}$ for 14 days. Also systematic depression in Menthol content under the $60,80,100$ and $120^{\circ} \mathrm{C}$ comparing with the extraction of oil from the fresh mint leaves.

Cineol, Limonene, Carvone, Myrecene, $\alpha$-Pinene and $\beta$-Pinene concentrations in mint oil were not significantly different in fresh leaves or after drying with $40^{\circ} \mathrm{C}$. No significant differences were found between the oil contents from Cineol and Limonene under the drying of $60^{\circ} \mathrm{C}$ and $80^{\circ} \mathrm{C} / 14$ days, while significantly decreasing in their concentrations under $100^{\circ} \mathrm{C}$ and $120^{\circ} \mathrm{C}$ without significant difference between both drying treatments. Carvone, Myrecene and $\alpha$-Pinene contents negatively responded to increasing drying temperature after $40^{\circ} \mathrm{C}$ without significantly difference between drying under $100^{\circ} \mathrm{C}, 120^{\circ} \mathrm{C}$.

The reduction in the concentrations of Carvone, Myrecene, $\alpha$-Pinene and $\beta$-Pinene under $100^{\circ} \mathrm{C}$ drying $/ 14$ days comparing with $60^{\circ} \mathrm{C} / 14$ days were $17 \%, 23 \%, 22.5 \%$ and $25 \%$, respectively. These results showed the bad effects of the high temperature $\left(>40^{\circ} \mathrm{C}\right)$ on the terpene composition of the mint oil. The bad effects of the high drying temperature on terpene compounds (\%) of the essential oil may be due to the evaporation rate and the glycolytes oxidation of the terpenes in the essential oil under the high temperature drying post harvest time before the extraction. Als, as drying temperature of the mint leaves decreased the mint oil monoterpene percentage increased, but when the drying temperature increased glucolytes oxidation increased and accordingly percentage of the main terpene compoyund especially menthol and menthone sighnificantly decreased (Muffei \& Codignola, 1990). 
Table 2. Means of essential oil (\%) and its terpene compounds (\%) of mint under the drying temperatures over the 2 mint genotypes

\begin{tabular}{lllllll}
\hline \multirow{2}{*}{ Composition } & \multicolumn{5}{c}{ Means $(\%)$} \\
\cline { 2 - 6 } & Without drying & $40^{\circ} \mathrm{C}$ & $60^{\circ} \mathrm{C}$ & $80^{\circ} \mathrm{C}$ & $100^{\circ} \mathrm{C}$ & $120^{\circ} \mathrm{C}$ \\
\hline Essential oil content & $1.44 \mathrm{a}^{*}$ & $1.40 \mathrm{a}$ & $1.32 \mathrm{~b}$ & $1.13 \mathrm{c}$ & $1.01 \mathrm{~d}$ & $0.92 \mathrm{~d}$ \\
Menthone & $16.24 \mathrm{a}$ & $16.73 \mathrm{a}$ & $16.15 \mathrm{a}$ & $15.85 \mathrm{~b}$ & $15.13 \mathrm{~b}$ & $15.10 \mathrm{~b}$ \\
Iso-Menthone & $7.54 \mathrm{ab}$ & $7.63 \mathrm{a}$ & $7.27 \mathrm{bc}$ & $7.06 \mathrm{~cd}$ & $6.92 \mathrm{~cd}$ & $6.81 \mathrm{~d}$ \\
Menthol & $51.51 \mathrm{a}$ & $52.08 \mathrm{a}$ & $49.15 \mathrm{ab}$ & $47.01 \mathrm{bc}$ & $44.68 \mathrm{c}$ & $43.28 \mathrm{c}$ \\
Cineol & $3.77 \mathrm{a}$ & $3.84 \mathrm{a}$ & $3.66 \mathrm{~b}$ & $3.57 \mathrm{~b}$ & $3.48 \mathrm{c}$ & $3.45 \mathrm{c}$ \\
Limonene & $2.30 \mathrm{a}$ & $2.35 \mathrm{a}$ & $2.15 \mathrm{~b}$ & $2.09 \mathrm{~b}$ & $1.97 \mathrm{c}$ & $1.93 \mathrm{c}$ \\
Carvone & $1.05 \mathrm{~b}$ & $1.14 \mathrm{a}$ & $1.05 \mathrm{~b}$ & $0.90 \mathrm{c}$ & $0.83 \mathrm{~d}$ & $0.82 \mathrm{~d}$ \\
Myrecene & $0.83 \mathrm{~b}$ & $0.88 \mathrm{a}$ & $0.78 \mathrm{~b}$ & $0.72 \mathrm{c}$ & $0.68 \mathrm{~d}$ & $0.66 \mathrm{~d}$ \\
$\alpha-P i n e n e$ & $0.74 \mathrm{a}$ & $0.80 \mathrm{a}$ & $0.74 \mathrm{~b}$ & $0.65 \mathrm{c}$ & $0.62 \mathrm{c}$ & $0.54 \mathrm{~d}$ \\
$\beta-$ Pinene & $1.07 \mathrm{~b}$ & $1.14 \mathrm{a}$ & $1.10 \mathrm{a}$ & $0.95 \mathrm{~b}$ & $0.85 \mathrm{c}$ & $0.80 \mathrm{c}$ \\
\hline
\end{tabular}

*, Means followed by the same letter are not significantly different according to BLSD at $\mathrm{p} \leq 0.01$, respectively.

\subsection{Regression Analysis}

Results of the regression analysis of the relation between essential oil and the 9 terpene components of mint oil and the 6 drying temperature treatments before oil distillation over the 2 genotypes are presented in Table 3 . The regression coefficients of essential oil and the 9 terpene components were significant at $\mathrm{P} \leq 0.0001$, and had the negative trend. The adjusted determination coefficients ranged from 0.97 for Cineol to 0.69 for Menthone, Essential oil, Limonene and Carvone.

Table 3. Regression analysis of the relation between drying temperatures and mint essential oil and its terpene components

\begin{tabular}{lccccc}
\hline \multirow{2}{*}{ Characteristics } & Mean & Intercept & $\begin{array}{c}\text { Regression } \\
\text { Coefficient }\end{array}$ & $\begin{array}{c}\text { Standard } \\
\text { Error }( \pm \mathrm{SD})\end{array}$ & $\begin{array}{c}\text { Adjusted determination } \\
\text { coefficient }\left(\mathrm{R}^{2}\right)\end{array}$ \\
\cline { 3 - 6 } E. oil content & 1.195 & 1.538 & $-0.005^{* * *}$ & 0.0003 & 0.91 \\
Menthone & 15.850 & 16.694 & $-0.013^{* * *}$ & 0.0017 & 0.69 \\
Iso-Menthone & 7.176 & 7.706 & $-0.008^{* * *}$ & 0.0008 & 0.82 \\
Menthol & 47.87 & 52.632 & $-0.071^{* * *}$ & 0.006 & 0.85 \\
Cineol & 2.854 & 3.723 & $-0.013^{* * *}$ & 0.0005 & 0.97 \\
Limonene & 2.075 & 2.371 & $-0.004^{* * *}$ & 0.0003 & 0.91 \\
Carvone & 0.872 & 1.099 & $-0.003^{* * *}$ & 0.0002 & 0.91 \\
Myrecene & 0.738 & 0.886 & $-0.002^{* * *}$ & 0.0002 & 0.85 \\
$\alpha-P i n e n e$ & 0.674 & 0.815 & $-0.002^{* * *}$ & 0.0002 & 0.76 \\
$\beta$-Pinene & 0.983 & 1.174 & $-0.003^{* * *}$ & 0.0004 & 0.70
\end{tabular}

${ }^{* * *}$ : Significant at $\mathrm{P} \leq 0.001$.

As, a conclusion from this regression analysis that as drying temperature increased by $1^{\circ} \mathrm{C}$, essential oil decreased by $0.005 \%$ and 2 the main terpene components (Menthone and Menthol) decreased by 0.013 and $0.071 \%$, respectively. These results showed the adversely effect of high drying temperature on mint essential oil and its terpene components. 


\subsection{Correlation Analysis}

Correlation analysis between the 10 mints studied characteristics including essential oil and 9 terpene components over the 2 mint genotypes (Table 4) showed significant, positive correlations between essential oil and all terpene components with (r) values ranged from 0.96 with Menthol to 0.80 with Myrecene, and the highest correlation coefficients were found with Menthol (0.96), Menthone (0.94) and Is-Menthone (0.90). The main terpene in the mint essential oil (Menthol) significantly and negatively correlated with Menthone (- 0.64$)$, Iso-Menthone (- 0.74), Cineol (- 0.65), Limonene (- 0.067), Carvone (- 0.59) and $\beta$-Pinene (- 0.82), while it positively correlated with Myrecene (0.72) and Pinene (0.76). Menthone is the $2^{\text {nd }}$ main component in the mint oil, and positively and significantly correlated with Cineol (0.81), Limonene (0.89), Carvone (0.82) and $\beta$-Pinene (0.79), while it negatively correlated with Iso-Menthone (- 0.56), Menthol (- 0.64), Myrecene (- 0.65) and $\alpha$-Pinene (- 0.75).

Significantly correlations were showed among the other oil terpenes, but the direction of the relation different between the positive or negative as shown in (Table 3).

Table 3. Correlation coefficients between each of essential oil and 9 terpene components

\begin{tabular}{|c|c|c|c|c|c|c|c|c|c|}
\hline \multirow[b]{2}{*}{ Characteristics } & \multicolumn{9}{|c|}{ Characteristics } \\
\hline & $\begin{array}{l}\frac{3}{0} \\
\stackrel{0}{0} \\
\stackrel{0}{0}\end{array}$ & 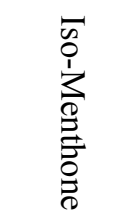 & $\begin{array}{l}3 \\
\stackrel{3}{0} \\
\stackrel{0}{0}\end{array}$ & 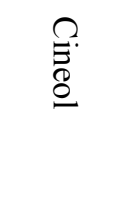 & 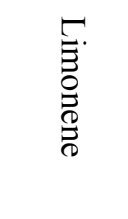 & $\begin{array}{l}\text { श्र } \\
\text { हैं } \\
\text { है }\end{array}$ & 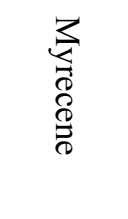 & 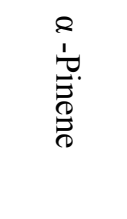 & 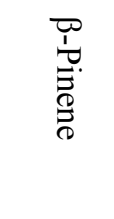 \\
\hline Essential oil & $0.94^{* *}$ & $0.90^{* *}$ & $0.96^{* *}$ & $0.86^{* *}$ & $0.85^{* *}$ & $0.83^{* *}$ & $0.80^{* *}$ & $0.81^{* *}$ & $0.82^{* *}$ \\
\hline Menthone & & $-0.56^{* *}$ & $-0.64^{* *}$ & $0.81^{* *}$ & $0.89^{* *}$ & $0.82^{* *}$ & $-0.65^{* *}$ & $-0.75^{* *}$ & $-0.79^{* *}$ \\
\hline Iso-Menthone & & & $-0.74^{* *}$ & $0.90^{* *}$ & $0.96^{* *}$ & $0.97^{* *}$ & $0.98^{* *}$ & $0.94^{* *}$ & $-0.66^{* *}$ \\
\hline Menthol & & & & $-0.65^{* *}$ & $-0.67^{* *}$ & $-0.59^{* *}$ & $0.72^{* *}$ & $0.76^{* *}$ & $-0.82^{* *}$ \\
\hline Cineol & & & & & $0.96^{* *}$ & $0.95^{* *}$ & $0.92^{* *}$ & $0.86^{* *}$ & $0.81^{* *}$ \\
\hline Limonene & & & & & & $-0.80^{* *}$ & $-0.85^{* *}$ & $0.90^{* *}$ & $0.86^{* *}$ \\
\hline Carvone & & & & & & & $0.98^{* *}$ & $0.94^{* *}$ & $0.89^{* *}$ \\
\hline Myrecene & & & & & & & & $0.95^{* *}$ & $0.93^{* *}$ \\
\hline$\alpha$-Pinene & & & & & & & & & $-0.86^{* *}$ \\
\hline
\end{tabular}

$* *$ Significant at $\mathrm{P} \leq 0.01$.

\section{Conclusion}

Significant differences were showed between the 2 studied mint genotypes in essential oil and the main terpene components. No significant differences were found between the essential oil contents under fresh or $40^{\circ} \mathrm{C}$ drying treatments but it significantly decreased over $40^{\circ} \mathrm{C}$ drying. Menthone and Menthol significantly decreased as drying temperature was $>60^{\circ} \mathrm{C}$. As drying temperature increased by $1{ }^{\circ} \mathrm{C}$, essential oil decreased by $0.005 \%$ and Menthone and Menthol decreased by 0.013 and $0.071 \%$, respectively. The highest correlation coefficients were found between essential oil (\%) and Menthone and Menthole were 0.96 and 0.94 , respectively.

\section{Acknowledgments}

This project was funded by the Deanship of Science Research (DSR), King Abdulaziz University, Jeddah under grant no. (22/155/1433). The authors therefore acknowledge with thanks DSR, technological and financial support.

\section{References}

Adams, R. P. (2001). Identification of Essential Oil Components by Gas Chromatography/Quadrupole Mass Spectroscopy. Allured Publishing Corporation, Carol Stream (IL).

AOAC. (2000). Association of Official Analytical Chemists. Official methods of analysis (17th ed.). Washington DC. 
Arabhosseini, A., Huisman, W., van Boxtel, A., \& Müller, J. (2007). Long-term effects of drying conditions on the essential oil and color of tarragon leaves during storage. Journal of Food Engineering, 79(2), 561-566. http://dx.doi.org/10.1016/j.jfoodeng.2006.02.014

Chalchat, J. C., Garry, R. P., \& Michet, A. (1997). Variation of the chemical composition of essential oil of Mentha piperita L. during the growing time. Journal of Essential Oil Research, 9, 463-465. http://dx.doi.org/10.1080/10412905.1997.9700750

Clark, R. J., \& Menary, R. C. (1980) Environmental effects on peppermint, I. Effect of day length, photon flux density, night temperature and day temperature on yield and composition of peppermint oil. Aust J Plant Physiol, 7, 685-692. http://dx.doi.org/10.1071/PP9800685

Croteau, R. B, Davis, E. M, Ringer, K. L., \&Wildung, M. R. (2005). (-)-Menthol biosynthesis and molecular genetics. Naturwissenschaften, 92(12), 562-77. http://dx.doi.org/10.1007/s00114-005-0055-0

El-Nakhlawy, F. S. (2010). Experimental Design and Analysis in Scientific Research. Sci. Pub. Center, king Abdulaziz University, Jeddah, Saudi Arabia.

Fennell, C. W., Light, M. E., Sparg, S. G., Stafford, G. I., \& van Staden, J. (2004). Assessing African medicinal plants for efficacy and safety: agricultural and storage practices. Journal of Ethnopharmacology, 95(2-3), 113-121. http://dx.doi.org/10.1016/j.jep.2004.05.025

Franz, C. H., Hölzl, J., Ceylan, A., \&Vömel, A. (1984). Influence of the growing site on the quality of Mentha piperita oil. Acta Horticulturae, 144, 145-150.

Kofidis, G., Bosabalidis, A. M., \& Kokkini, S. (2004). Seasonal variation of essential oils in a linalool rich chemotype of Mentha spicata grown wild in Greece, J. Essent. Oil Res., 16, 469-472. http://dx.doi.org/10.1080/10412905.2004.9698773

Kumar, S., Bahl, J. R., Bansal, R. P., Kukreja, A. K., Garg, S. N., Naqvi, A. A., ... Sharma, S. (2000). Profiles of the essential oils of Indian menthol mint (Mentha arvensis) cultivars at different stages of crop growth in northern plains. Journal of Medicinal and Aromatic Plants Sciences, 22, 774-786.

Maffei, M., \& Codignola, A. (1990). Photosynthesis, photorespiration and herbicide effect on terpene production in peppermint (Mentha piperita L.). J. Essent. Oil Res., 2, 275-286. http://dx.doi.org/10.1080/10412905.1990.9697886

Masada, Y. (1976). Analysis of Essential Oils by Gas Chromatography and Mass Spectrometry. John Wiley \& Sons Inc.

McCaskill, D., Gershenzon, J., \& Croteau, R. (1992). Morphology and monoterpene biosynthetic capabilities of secretory cell clusters isolated from glandular trichomes of peppermint (Mentha piperita). Planta, 187, 445-454. http://dx.doi.org/10.1007/BF00199962

Rohloff, J. (1999). Monoterpene composition of essential oil from peppermint (Mentha piperita L.) with regard to leaf position using solid-phase microextraction and Gas Chromatography/Mass Spectrometry Analysis. $J$. Agric. Food Chem., 47(9), 3782-3786. http://dx.doi.org/10.1021/jf981310s

SAS. (2006). SAS Institute Inc., Cary Nc., USA (Soft Ware Statistical Program).

Singh, A. K., Singh, K., Naqvi, A. A., \& Thakur, R. S. (1990). Effect of storage of herb on the quality and yield of oil in mint species. Research and Industry, 35(1). 46-48.

\section{Copyrights}

Copyright for this article is retained by the author(s), with first publication rights granted to the journal.

This is an open-access article distributed under the terms and conditions of the Creative Commons Attribution license (http://creativecommons.org/licenses/by/3.0/). 